\title{
Romanian insurance business trends and the International crisis effects on it
}

\author{
Cosmin Joldes and Alexandra Horobet
}

\author{
Academy of Economic Studies Bucharest, 6 Piata Romana, Bucharest-1, Romania
}

\begin{abstract}
Is it interesting a 2 billion euro insurance market for the "old" Europe? "Not very much" one may say considering this figure represents no more than $16 \%$ of the insurance turn-over in the case of the most recent entry in the Romanian market, Groupama. The answer is still not as simple as that because "interesting" in business terms is not only about today, but very much about tomorrow. By the end of 2007 it was obvious that the Romanian insurance market is far from calming down. Not only that for the time being change is still the main real constant in use, but figures show that the market environment becomes more challenging than ever these days. The market situation showed that this allegation it was by that time more likely to be true than ever.
\end{abstract}

Key words: insurance, trends, crisis, change, strategies

\section{Introduction}

Within the first half of 2008 there were some trends emerge or consolidate on the Romanian insurance market. Here are only some of them: the motor hull insurance business line remains the undisputed market leader, although the claims ratios and volumes in motor insurance are still mounting and piling up. Still, there is a visible trend among insurers to migrate towards business segments with lower claims ratios -good examples being the fall in volumes on the credit and warranties segment and the efforts to increase penetration on the property lines.

How all these trends were affected by the international crisis? How will be the short and long terms of the effects on the Romanian market? This paper will have all these, as a principal focus.

\section{Recent evolutions of the Romanian insurance market}

The Romanian insurance market overcame a total amount of revenues of 1.8 billion euro during the first 9 months of 2008. Compared to the value recorded within the similar period of 2007, the nominal growth in euro amounted $13.54 \%$ almost twice lower than the value of the same indicator recorded at the end of September 2007. Even if there are not official data yet, keeping the growing trend, the value of the Romanian insurance market, expressed in gross written premiums, reached by the end of 2008 a total of 2.38 billion euro ( 8.78 billion Romanian leu). This is a nominal growth in the European currency, with almost $11 \%$ compared to 2007. The increase in nominal national currency underwritings was of $22.4 \%$ compared to the prior year, comparable with the growth of $25.25 \%$ in 2007. Meanwhile, the claims dynamics was $34 \%$ in national currency, gross allowances paid by insurers in 2008 amounting RON 4.4 billion, meaning EUR 1.2 billion.

In the first 9 months of 2008, the absolute value of the insurance market grows with 220 million euro. The absolute growing amounted 55 million euro on the life insurance field, while the non-life insurance classes cumulated a consolidate growing which exceeded 164 million euro. The increasing in the Motor Hull segment overcame 172 million euro, the Motor Third Part Liability insurance grew with about 11 million euro, while the Property insurance grew with 36 million euro. In the same period, The Credit and Warranties insurance recorded a decrease by 50 million euro.

Table 1. TOP 10: All Insurance Lines in Romania (2008)

\begin{tabular}{|c|c|c|c|}
\hline Nr. & Company & $\begin{array}{c}\text { Gross Written } \\
\text { Premiums (mil euro) }\end{array}$ & $\begin{array}{c}\text { Market } \\
\text { Share (\%) }\end{array}$ \\
\hline 1 & Allianz - Tiriac & 375.9 & 15.8 \\
\hline 2 & Omniasig & 327.7 & 13.7 \\
\hline 3 & Asirom & 203.1 & 8.5 \\
\hline 4 & Astra & 177.8 & 7.5 \\
\hline 5 & Asiban & 164.8 & 6.9 \\
\hline 6 & ING Asigurari deViata & 164.1 & 6.9 \\
\hline 7 & BCR Asigurari & 147.6 & 6.2 \\
\hline 8 & Unita & 135.1 & 5.7 \\
\hline 9 & Generali & 113.2 & 4.7 \\
\hline 10 & Ardaf & 95.8 & 4.0 \\
\hline & Total TOP 10 & $1,905.1$ & 79.9 \\
\hline & Total Market & $\mathbf{2 , 3 8 5 . 0}$ & $\mathbf{1 0 0 . 0}$ \\
\hline
\end{tabular}

Source: The Insurance Supervisory Commission

In the first 9 months of 2008, the nominal growth recorded on the Motor Third Part Liability segment was about $3 \%$, with about 10 percentage point less than the 
market average, even if the mention insurance class grew by 11 million euro. This development conducted to the decrease of this insurance class in the total amount of gross written premium. It held $23.26 \%$ from the insurance industry after the first 9 months of 2007. In 2008, by the end of this period, the Motor Third Part Liability insurance class represents $21 \%$ from the total amount of premiums, with 2 percentage point less than during the first three quarters of the preceding year. One consequence for this evolution is the decreasing recorded on the credit and warranties sector. The Motor Hull insurance recorded a growing of more than 30 percentage point, more than double comparing with the market average. The increased share of the Motor Hull insurance is with 5 percentage points in the market, up to $40.17 \%$ of it. Other changes in the market, on the consolidate portfolio on insurance classes, except the one already mentioned, took place also on the life insurance field +0.7 percentage points up to a share of $11.92 \%$ from the market amount.

According to provisional data announced by the Insurance Supervisory Commission (CSA) for 2008, the total underwritings from the general insurance reached to $79.5 \%$ of the total gross written premiums, meaning less than RON 7 billion (EUR 1.9 billion). The $21.96 \%$ underwritings dynamics on this segment was exceeded significantly by the claims paid, which rose to $35.5 \%$. Thus, gross allowances paid on general insurance business class, worth RON 4.2 billion, represented $95.4 \%$ of the total claims.

Due to their growth with $34.72 \%$, the underwritten insurance premiums on Motor Hull insurance have increased by almost 5 percentage points in share of total underwritings in general insurance up to $50.5 \%$ in 2008 , compared to $45.7 \%$ in 2007. The Motor Third Part Liability insurance rose in 2008 to $20.58 \%$, which made their share in the non-life segment to decline from $26.2 \%$ in 2007 to $25.9 \%$.

The claims paid for Motor Hull insurance represent 59.6\% of the total (5\% more than in 2007) and the ones related to the Motor Third Part Liability insurance class represent $29.5 \%$ (2.4\% more than in 2007). Allowances paid to each of these two classes have registered comparable nominal growth in 2008, meaning $47.30 \%$ in Motor Third Part Liability insurance, and

Table 2. TOP 10: Non-life Insurance in Romania (2008)

\begin{tabular}{|c|c|c|c|}
\hline Nr. & Company & $\begin{array}{c}\text { Gross Written } \\
\text { Premiums (mil euro) }\end{array}$ & $\begin{array}{c}\text { Market } \\
\text { Share (\%) }\end{array}$ \\
\hline 1 & Allianz - Tiriac & 347.2 & 18.3 \\
\hline 2 & Omniasig & 327.7 & 17.3 \\
\hline 3 & Asirom & 178.3 & 9.4 \\
\hline 4 & Astra & 175.8 & 9.3 \\
\hline 5 & BCR Asigurari & 146.6 & 7.8 \\
\hline 6 & Asiban & 135.4 & 7.1 \\
\hline 7 & Unita & 135.1 & 7.1 \\
\hline 8 & Ardaf & 95.5 & 5.0 \\
\hline 9 & Generali & 90.0 & 4.7 \\
\hline 10 & BT Asigurari & 82.3 & 4.3 \\
\hline & Total TOP 10 & $1,715.0$ & 90.4 \\
\hline & Total Market & $\mathbf{1 , 8 9 6 . 6}$ & $\mathbf{1 0 0 . 0}$ \\
\hline
\end{tabular}

Source: The Insurance Supervisory Comission
$47.71 \%$ in Motor Hull insurance, according to the provisional data communicated by the CSA for 2008 .

On the credit insurance class underwritings have continued to decline in 2008 , with $51.87 \%$ compared to 2007 , a trend that declined their share in the total gross written premiums in general insurance to $2.7 \%$ in 2008, compared to $6.9 \%$ in 2007 and, respectively, $8.6 \%$ in 2006 . Claims paid on this segment were also reduced with $54.56 \%$ compared to the previous year.

Life insurance generated in 2008 gross written premiums of almost RON 1.8 billion (488.3 million euro), representing $20.5 \%$ of the total underwritings in the market. The growth on this segment was, as in 2007, superior to the dynamics of the general insurance, amounting to $24.11 \%$. The claims paid in life insurance totaled 204 million Romanian leu, up 8.64\% compared to 2007.

Table 3. TOP 10: Life Insurance in Romania (2008)

\begin{tabular}{|c|c|c|c|}
\hline Nr. & Company & $\begin{array}{c}\text { Gross Written } \\
\text { Premiums (mil euro) }\end{array}$ & $\begin{array}{c}\text { Market } \\
\text { Share (\%) }\end{array}$ \\
\hline 1 & ING Asigurari deViata & 164.1 & 33.6 \\
\hline 2 & AIG Life & 77.7 & 15.9 \\
\hline 3 & BCR Life & 43.5 & 8.9 \\
\hline 4 & Asiban & 29.4 & 6.0 \\
\hline 5 & Aviva & 29.3 & 6.0 \\
\hline 6 & Allianz-Tiriac & 28.7 & 5.9 \\
\hline 7 & Asirom & 24.8 & 5.1 \\
\hline 8 & Grawe & 23.4 & 4.8 \\
\hline 9 & Generali & 23.2 & 4.8 \\
\hline 10 & Omniasig Life & 13.8 & 2.8 \\
\hline & Total TOP 10 & 457.8 & 93.8 \\
\hline & Total Market & $\mathbf{4 8 8 . 4}$ & $\mathbf{1 0 0 . 0}$ \\
\hline
\end{tabular}

Source: The Insurance Supervisory Commission

By the end of the third quarter of 2008, the insurance companies paid in Romania, more than 800 billion euro claims, rising with about $14.17 \%$ as compared with the value of the same indicator recorded during the corresponding period of 2007. It is obvious that the claims dynamic overcame by little the rising recorded on the gross written premiums segment. In the meanwhile, the claims paid for Motor Hull insurance grew, in an absolute value, with more than 140 million euro more than the value of the mentioned indicator recorded during the first three quarters of 2007. During the analyzed period the insurance companies owned gross technical reserves for non-life insurance amounting about 1.6 billion euro. These reserves were covered by assets amounting 1.9 billion euro, thus in a share of $118.4 \%$. In the case of the life insurance activity, the gross technical reserves amounted about 900 million euro, covered by assets that totaled about 1 billion euro meaning a covering of $115.14 \%$.

\section{Romanian Market Leaders}

By the end of the third quarter of 2008, the first ten companies in the Romanian insurance market, ranked by market share totaled, gross premium that exceeded 1.45 
billion euro, meaning about $79.3 \%$ from life insurance. Thus, the concentration degree of the market decreased by 1 percentage point as compared to the value of the similar indicator recorded during the first 9 months of 2007. The absolute value of the premiums written by the first 10 companies in the market grew by 157 million euro.

For the first time as market evolution, 7 companies from Top10 insurers recorded growing rates below the market average, thus losing market share. In absolute value, the evolution recorded among the top 10 companies differs from -28.71 million euros up to +65.22 million euro. The first 3 companies in the hierarchy kept its position while 4 among the top 10 companies change their places. BT Asigurari left the top 10 and switched places with Ardaf company which came back in top 10 .

Allianz-Tiriac is still the Romanian market leader. This company recorded a nominal increase in euro, by $2.03 \%$, with about 11 percentage points below market's average. Allianz-Tiriac wrote gross premiums amounting more than 283 million euro, with 5.64 million euro more than the value recorded by the company during the corresponding period of 2007. The company's growing rate evolution lead to a market share loss of about 1.74 percentage points. The claims paid by the company overcame 149 million euro and the market share reached $15.44 \%$.

\section{Insurance Density in Romania}

For a more qualitative insurance market analysis, we may take into consideration the market density which varies a lot among the Romanian counties. Only inhabitants from Bucharest and Cluj (Transylvania) spend over 100 euro/year for insurance products.

Table 4. Insurance Density Evolution in Romania (2007/2006)

\begin{tabular}{|c|l|c|c|c|}
\hline Nr. & County & \multicolumn{2}{|c|}{ Insurance density (euro) } & Evolution (euro) \\
\hline & & $\mathbf{2 0 0 7}$ & $\mathbf{2 0 0 6}$ & \\
\hline 1 & Bucharest & 513.30 & 394.19 & 119.11 \\
\hline 2 & Cluj & 105.02 & 72.17 & 32.85 \\
\hline 3 & Sibiu & 88.94 & 131.14 & -42.20 \\
\hline 4 & Arges & 84.19 & 50.35 & 33.84 \\
\hline 5 & Buzau & 80.09 & 59.70 & 20.39 \\
\hline 6 & Timis & 77.22 & 59.15 & 18.07 \\
\hline 7 & Brasov & 74.49 & 51.18 & 23.31 \\
\hline 8 & Arad & 70.91 & 52.93 & 17.98 \\
\hline 9 & Constanta & 65.42 & 48.96 & 16.46 \\
\hline 10 & Hunedoara & 59.85 & 39.75 & 20.10 \\
\hline
\end{tabular}

Source: 2007 Romanian Statistical Yearbook, National Institute of Statistics

If an inhabitant of the Romanian capital Bucharest spent an average of 513.3 euro, in 2007, for insurance products, a resident of Cluj-Napoca spent 105.02 euro. On the opposite side there are the counties of Botosani, Teleorman and Vaslui, where inhabitants spent an average of about 25 euro for insurance products, in 2007. Compared with 2006, the increasing of the largest absolute value insurance density was recorded in Bucharest (119 euro), in the counties of Arges (33.84 euro) and Cluj (32.85 euro), while the only decreasing was recorded in the county of Sibiu (-42.20 euro).

\section{Is 2009 the year of challenges?}

The year 2009 is considered already one of the most challenging years for Romanian insurance market. This is on one hand because of the present financial crisis worldwide and on the other hand, as a consequence of many legislative changes that may apply this year (as the mandatory Law of Property Insurance, etc.)

The financial crisis, at the first sight, and its result -the international economic crisis that the global economy is facing has shaken many international auto manufacturers, in respect of the considerable reduction in the sales volume, compared to the same period a year earlier. Romania, as many other countries, experienced already the significant decline of the demand for motor vehicles, if we relate to sales recorded in the previous year, especially against the backdrop of restricting lending. In the same time, the local profile of the insurance market is dominated by motor insurance, with more than 60 percent of all underwritings made in 2008. Moreover, the motor sector has been and is being viewed also for 2009 as a real "growth engine for the Romanian insurance market", according to the market specialists. Therefore, this reduction in sales, recorded in Europe, could have an indirect strong influence on sales of Motor Third Part Liability and Motor Hull policies in Romania.

Moreover, beside motor insurance class, other insurance segments, such as life insurance (especially the unit-linked products) could be affected by the economic crisis in Romania.

The expected Romanian legislative changes concerning insurances represent a second major challenge for 2009. Most of these changes are laws whose adoption has led various contradictory debates. First of all, from the 1 st of January 2009, the holders of Motor Hull policies involved in a traffic incident that damaged only their own vehicle, or if the damage occurred in circumstances other than in a traffic accident, will not be forced to go to the police to draw input document in a car repair, but can directly go at the insurance companies' headquarters. Another change is that from the beginning of 2009, the Motor Third Part Liability policies will be issued in electronic format. The amicable report will enter into force from the 1st of July 2009, which notes that the road accidents with no victims, can be solved without police issued documents, provided that the form is filled and signed by both drivers involved in that accident.

From the mid of 2009, the house insurance policies will become mandatory for all immobile owners in Romania.

These changes involve a lot of internal infrastructure's investments in the case of insurance companies. They may develop information systems and additional training for agents, part of their sales force, may be needed. 
Another controversial law, issued by CSA, refers to the limitation of the insurance broker commission to $15 \%$ in the case of Motor Third Part Liability policies. This initiative generated negative reactions from the intermediaries, in terms of a free market of services.

These are only some to the reasons that may require a particular attention from the insurance companies in 2009, this year being considered to be the "Year of challenges".

\section{Conclusions}

For more than 10 years, the insurance market in Romania has witnessed a positive trend, the industry growing annually by about 30 percent, more than any country in Europe. This double digit market dynamic suffered already a reduction in 2008, the market managing to grow in the first nine months of 2008, "only" with $13.54 \%$, until a volume of underwritings of 1.8 billion euro, compared to the same period of 2007.

In this context, the full year 2008 means a less than 10 percent increase, compared to 2.2 billion euro, value recorded in 2007. The Romanian insurance specialists are skeptical considering the market development for 2009. This is contrary to one of the latest survey conducted by one of the most important insurance portal: "What is the anticipated evolution for the insurance market in Romania, in 2009?". The survey released that $55 \%$ of the 280 respondents expect a growing industry this year, between 0 and 20 percent, while $20 \%$ believe that the industry will register a decline. The rest of respondents trust that the market has a chance to increase by more than 20 percentage points.

If different stakeholders have different opinion about the market evolution in 2009, all of them consider by far that 2009 is the year when all insurers will be forced to operate as efficiently as possible, in order to maintain their growth and profitability within acceptable levels.

\section{References:}

Insurance Supervisory Commission (CSA) - Annual Reports, 2007 and 2008

National Association of Insurance and Reinsurance Companies (UNSAR) - Annual Reports, 2007 and 2008

Prim - Insurances \& Pensions, no.68, December 2008

Top Insurance Companies, Finmedia, December 2008

www.zf.ro

www.1asig.ro 